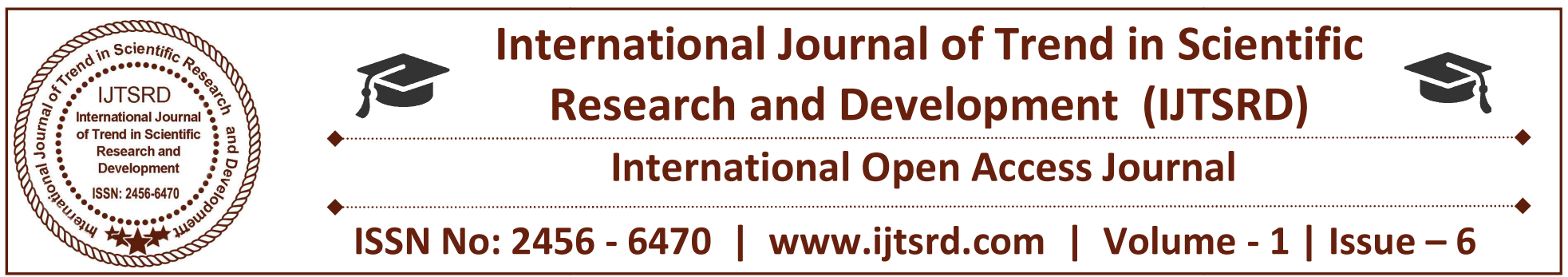

\title{
Field Geology and Petrography of Granitoid Rocks in southeastern part of Nanded District, Maharashtra State
}

\author{
P. R. C. Phani \\ Cyeint Limited, Plot\#11, Software \\ Units Layout, Infocity, \\ Madhapur, Hyderabad
}

\author{
N. Ningam \\ Department of Geology, \\ Osmania University, \\ Hyderabad
}

\author{
M. Srinivas \\ Department of Geology, \\ Osmania University, \\ Hyderabad
}

\section{ABSTRACT}

This paper presents field geological and petrographic aspects of various granitoid units occurring around Khatgaon area in the southeastern part of Nanded district of Maharashtra. The study area is bestowed with granitoids of Archaean to Proterozoic age overlain by Deccan basalts of Cretaceous age. Three main types of granitoids were identified in the study area viz., older granites, gneissic/foliated granites and younger granites. These granitoid rocks are traversed by dykes, veins and veinlets of felsic and mafic composition. Although these granitoids are similar in mineralogy, they exhibit differences in petrographic characteristics. The granitoids of the study area, especially the gneissic granitoids, comprise felsic and mafic lenticular enclaves of different sizes. Petrographically older and younger granitoids show medium to fine-grained, porphyritic and inequigranular textures. The gneissic rocks show foliation. At the contact of mafic enclaves and gneissic zones, conspicuous variation in mineralogy is observed in thin-sections. Presence of enclaves indicates coexistence and mixing of both felsic and mafic magmas at the source. The typical textures like perthitic, graphics and lamellar twinning indicate a direct magmatic origin for these granitoid rocks. The presence of pyrite mineralization at Khatgaon indicates late stage hydrothermal activity associated with felsic veins.

Keywords: Granitoid, Older granite, Younger granite, Granite gneiss, Field Geology, Petrography, Modal mineral abundance, Khatgaon, Maharashtra

\section{INTRODUCTION}

The Dharwar Craton of Indian subcontinent is divided into two main domains viz., Western Dharwar Craton (WDC) and Eastern Dharwar Craton (EDC) differentiated by the N-S linear Closepet Granite [1]. The predominant rock types in Dharwar Craton are granite and granitoid gneisses. Wasanekar studied geochronology and fluid inclusions of granitoidsof Degloor, occurring in the southern part of the present study area [2].

Owing to their mineralogical, geochemical and geodynamic variations, granitic rocks of peninsular India are of great interest to petrologists. Even though several workers have published reams of data on Dharwarian granitoids, still there exists a void in understanding their geology. The present study embraces field geological and petrographic characteristics of granites exposed near Khatgoan area, Nanded district of Maharashtra state. The earliest geological mapping was carried out by Hallowes (1918) [3]. Later, geological traverses and geochemical exploration were conducted by the GSI extensively in this area in search of mineralization like rare metals, tin-tungsten and allied metals in shear zones within the granite gneiss and granitoids, pegmatites, quartz veins, which still remain unpublished.Geomorphologically, the area forms a pediplain with undulatory with occasional residual hills/mounds of granitic composition. These granitic mounds are overlain by Deccan Trap basaltic rocks which have a lateritic capping resulted due to surface weathering and sedentary geomorphic processes. 
Field traverses have been conducted in the study area in 2016. The present study is confined to granitoid bodies only. The structural attitude was recorded using Brunton compass and GPS. Fresh outcrops were selected which possess different variations in granitic rocks, from quarries, vertical cliffs and surface exposures for petrographic study. About 15 samples have been collected for making thin-sections which were examined under research microscope at the Petrology Laboratory, Department of Geology, Osmania University, Hyderabad.The field and petrographic study helped to distinguish the different litho units and their relationship with each other in relation to their texture, mineralogy and mode of occurrence.

\section{GEOLOGICAL AND STRUCTURAL SETUP}

The study area (Figure 1) covers part of Survey of India (SoI) 1:250,000 toposheet 56F. During the field studies, it is observed that the area is imparted with three major units of granitoid rock types viz., older, younger and gneissic granitoids. These granitoids are part of the EDC [4].

The older granitoids include quartzo-feldspathic rocks represented by grey and pink varieties of Peninsular Gneissic Complex (PGC). The gneissic rocks are intensely foliated, weathered and friable in nature. The gneissic rocks contain mafic enclaves in the form of lenticular patches which appear to be undigested entities in which older granitoids were emplaced, according to discordant granitic veins in the gneissic enclaves as observed in field. The granitoid rocks are invariably and extensively traversed by veins and dykes of quartz, felsic pegmatite, aplite and mafic dykes. The basaltic flows overlie the older granitoids.Felsic veins and dykes are numerous intruding the older and gneissic granites. During field studies, it is observed that felsic veins are comparatively less in younger granites.

The felsic veins within granitoids of the study area, viz., aplite and pegmatite, possess a trend of NE-SW, EW and NNE-SSW to NNW- SSE exhibiting crisscross patterns (Fig.2 a and b). In pegmatitic veins, graphic intergrowth of quartz- feldspar phases at hand-scale have been observed. The mafic dykes represented by dolerites are widely spread in the area at villages Kundalwadi, Pipalgaon, Laghul, Sagroli, Shahpur etc. The dolerite shows typical ophitic texture (Fig.2c and d). The general trend of these dykes is ENE-WSW to NE-SW. However, the mafic and felsic dykes are not shown Figure 1. At places, felsic veins host sulphide mineralization.

The granitoids exhibit different types of structures like warping, multiple sets of joints, planar structures, lineations, micro faults and shear planes. The older granites possess three phases of foliations. Displacements are noticed within the intermixing felsic veins within granites. At places, intense shearing is observed leading to alignment of mineral grains (Fig. 3 a to d). 

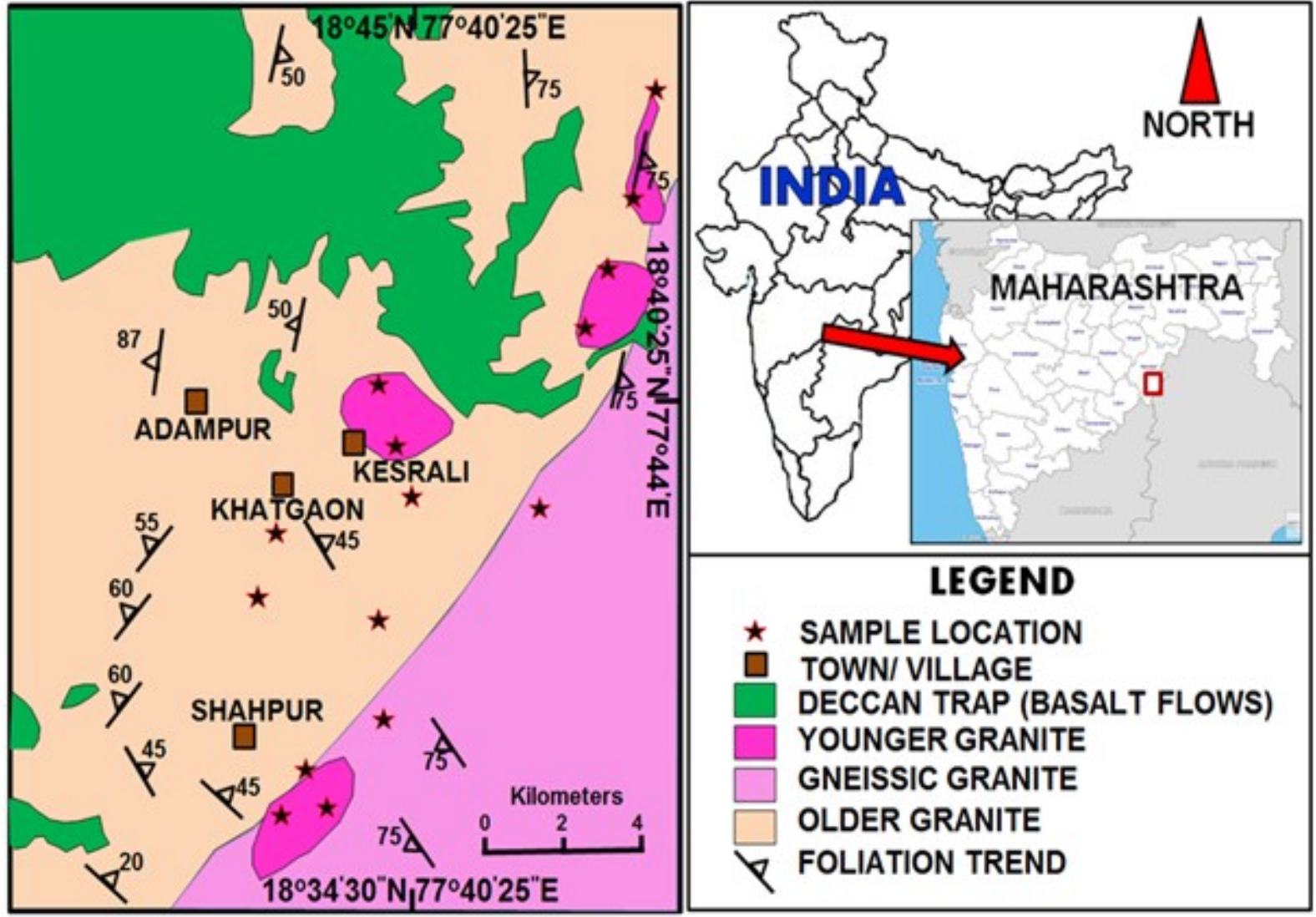

Figure 1. General geological map of the study area and petrography sample locations. Lithology interpreted with the aid of satellite image and Metallogenic Map [5].

The general geological succession of the area is as shown in Table 1.[6].

Table 1: General geological succession of the study area

\begin{tabular}{|c|c|c|}
\hline Age & Litho Unit & Lithology \\
\hline & Quaternary to Recent & Laterite, Alluvium, Soil \\
\hline $\begin{array}{c}\text { Upper } \\
\text { Cretaceous to } \\
\text { Lower } \\
\text { Palaeocene }\end{array}$ & $\begin{array}{c}\text { Deccan Trap } \\
\text { (Sahyadri Group) }\end{array}$ & Basalt Flows \\
\hline \multicolumn{3}{|c|}{ 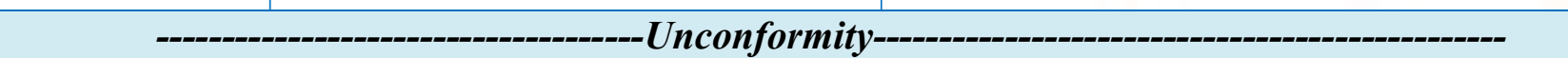 } \\
\hline \multirow{6}{*}{$\begin{array}{l}\text { Archaean to } \\
\text { Proterozoic }\end{array}$} & \multirow[t]{2}{*}{ Younger Intrusions } & Dolerite, Felsic Veins, Alkali granite \\
\hline & & Medium to coarse grained granite \\
\hline & \multirow[t]{3}{*}{ Peninsular Gneissic Complex } & Granodiorite \\
\hline & & Hornblende granite gneiss \\
\hline & & Amphibolite \\
\hline & Older Metamorphics & Hornblende schist \\
\hline
\end{tabular}




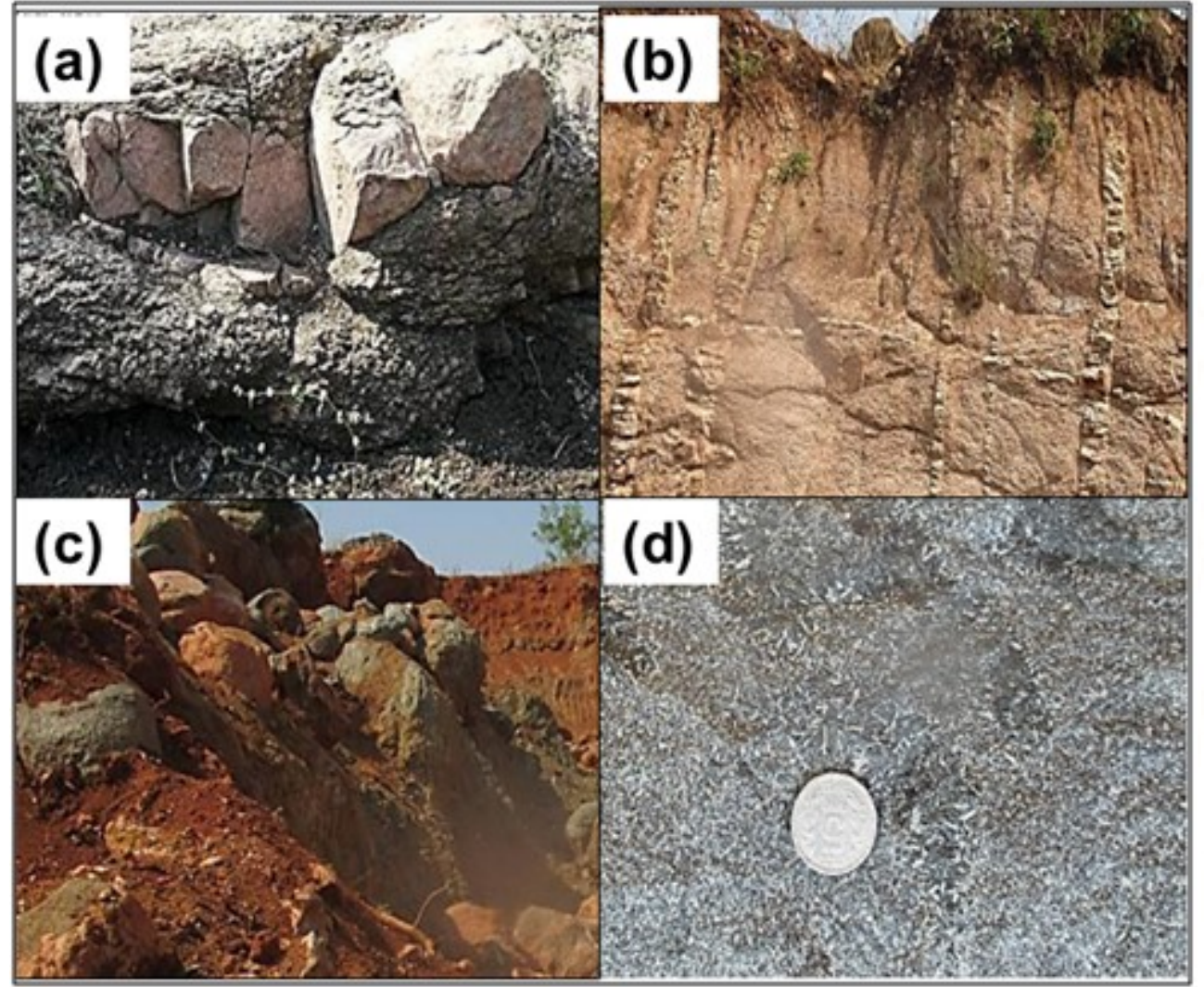

Figure 2: Rocks of the study area, other than granitoids. a- aplite intrusion in country rock granitoid. bfelsic pegmatite dykes, c- dolerite dyke boulders and d- ophitic texture in dolerite

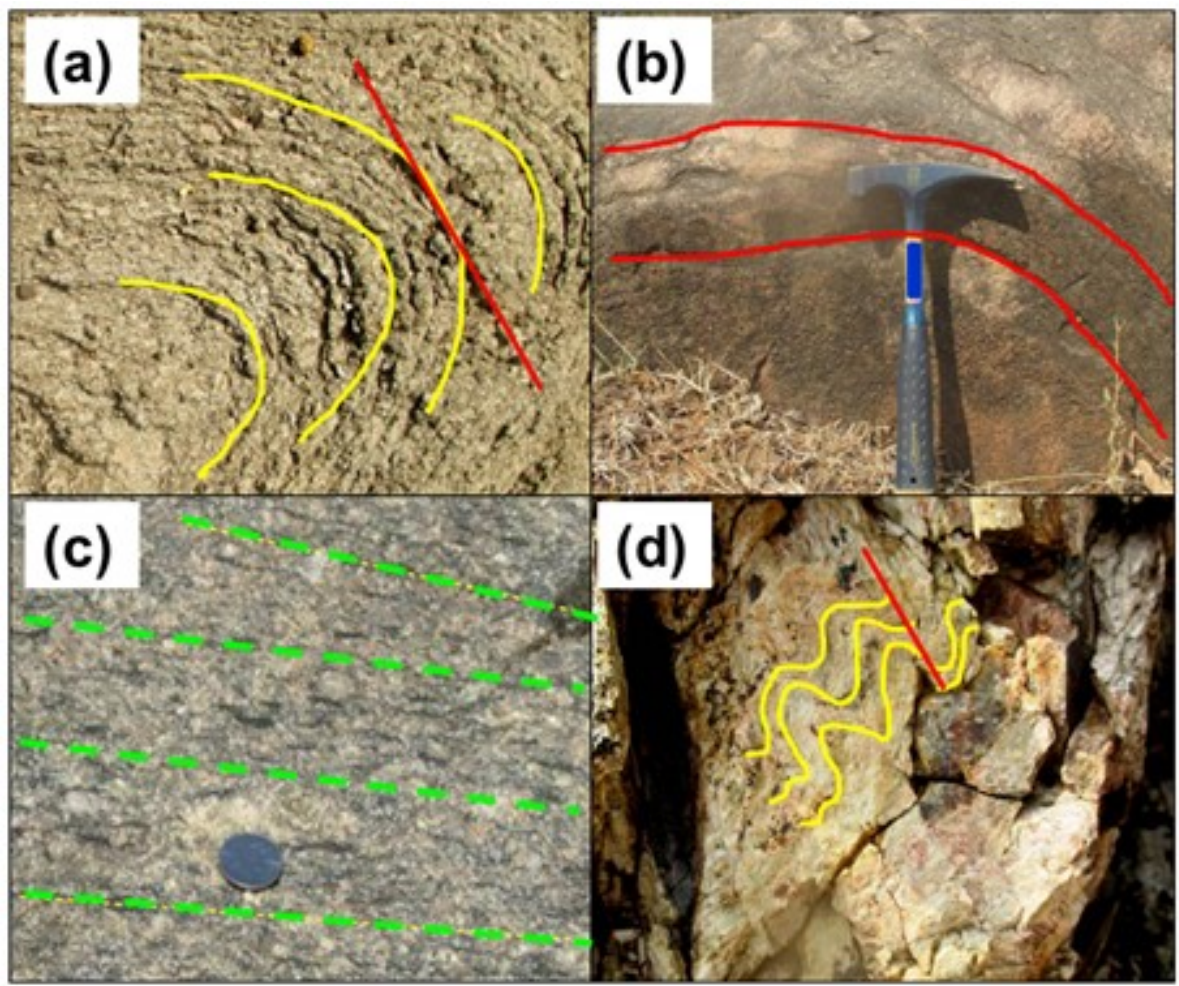

Figure 3: Structures in granites. a- foliations, b- warping, c- planar structure and d- folds in felsic pegmatite. Note plane of deformation (red line) in a and d 


\section{FIELD AND PETROGRAPHIC CHARACTERISTICS}

The field and petrographic descriptions of the granitoid rocks in the present study area are presented in the following discussion.

A. Gneissic Granitoids: The majority of the area is represented by the PGC quartzo-feldspathic granitoid gneisses with mafic enclaves. Although the gneissic rocks are strongly foliated and highly friable in nature, at places they are massive, compact and hard. These rocks are mesocratic, medium to coarse grained The foliated gneissic granitoids are highly friable due to weathering and show leucocratic with shades of pink and grey owing to the presence of microcline and orthoclase. These are medium to coarse grained contain flattened quartz, alkali feldspar, plagioclase, and strongly foliated (Fig. 4a). These gneisses comprise mafic mineral constituents like amphiboles, plagioclase and mica with minor quartz grains in hand specimens. The foliations are represented by parallel alignment of amphiboles and flattened feldspar tablets. These rocks are invariably intruded by granitic, pegmatitic and felsic veins. The mafic enclaves often occur as lensoid patches in the granitoids, which appear to be the undigested magmatic phases in which the older granitoids were emplaced (Fig. 4b). These enclaves are presumed to be the products of magma differentiation/mixing that primarily produced granites/granitoids $[7,8]$.

biotite and some minor ferromagnesian minerals. At Kahtgoan- Kesrali area, these gneissic rocks exhibit a gradational contact with older granitoids. In thinsections also, distinct foliation and enrichment of felsic minerals are observed (Fig. $4 \mathrm{c}$ and d).

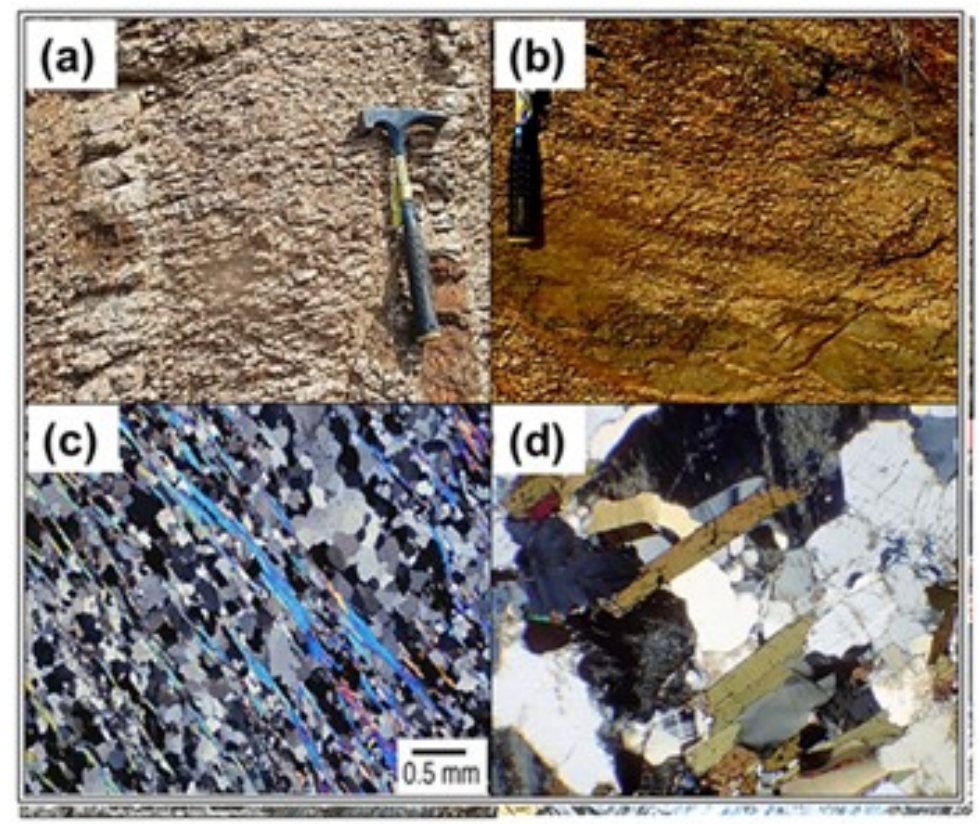

Figure 4.Field and microphotographs of Granite gneiss. a- granite gneiss showing foliation and felsic veins, b- intensely weathered granite gneiss with mafic enclave, c- photomicrograph of granite gneiss showing foliation and d-photomicrograph showing quartz- feldspar enrichment with minor mafics.

B. Older Granitoids: The older granitoids include both grey and pink granite varieties. The grey variety is leucocratic, often massive and occasionally weakly foliated. The grey granite is hard, compact, medium to coarse grained with occasional porphyritic texture. It is observed that, in hand specimens, this rock displays mineral constituents such as quartz, plagioclase, alkali feldspar, biotite and hornblende. In the felsic veins within these granites, veinlets, stringers, specks and disseminations of pyrite are observed in felsic veins at Khatgoan indicating late stage hydrothermal activity. The foliated pink granite, of older granitoids, is dark to light pink in colour, hard, compact, medium to coarse grained with porphyritic texture. At Shahpur, Sagroli and Hipaga area, pink and grey granites exhibit gradational contact. It contains quartz, alkali feldspar, plagioclase, biotite and iron oxides as its mineral ingredients. 
Under the microscope, the older granitoids display equigranular to inequigranular, coarse grained, perthitic, porphyritic and sieve intergrowth textures. The essential mineralogy includes quartz $(55-60 \%)$, plagioclase (15-20\%) and alkali feldspar (5-10\%) and minor mafics $(5-10 \%)$ including chlorite, epidote, sphene, biotite and iron oxides. The contact zone of plagioclase and alkali feldspar shows myrmekitic intergrowth.

The groundmass is mainly constitutes quartz, alkali feldspar and biotite with sericitised plagioclase. The alkali feldspar grains show perthitic texture and contain chlorite inclusions. The petrographic character of both grey and pink granite is more or less similar. The difference is seen in hand specimens by the presence of microcline (grey granite) and orthoclase (pink granite). Quartz exhibits undulose extinction and shows two distinct stages of crystallisation; solidification from the parental melt represented by anhedral coarse grains and late stage crystallisation forming fine graind with polygonal grain boundaries. The fractures are filled by biotite by secondary injection. Replacement of microcline by albite without changing the crystal habit denoted by hatched twinning is an interesting feature. Feldspar grains contain inclusions of quartz, plagioclase and other accessory minerals indicating compositional heterogeneity of the magma. The mineral biotite, shows altered grain boundaries giving rise to chloritisation is not uncommon. Biotite is often associated with altered opaque minerals and sphene grains. Sometimes, biotite exhibits flaky nature leading to foliated appearance (Fig. $5 \mathrm{c}$ and d). Similar feature are observed in pink granites(Fig. 6a to d).During the magmatic process, it appears that the major mineral constituents appear to have undergone metasomatic alteration. Alteration of albite to feldspar and development of secondary sphene are characteristic of pink granites of the study area (Fig. $7 \mathrm{a}$ and $\mathrm{b}$ ).

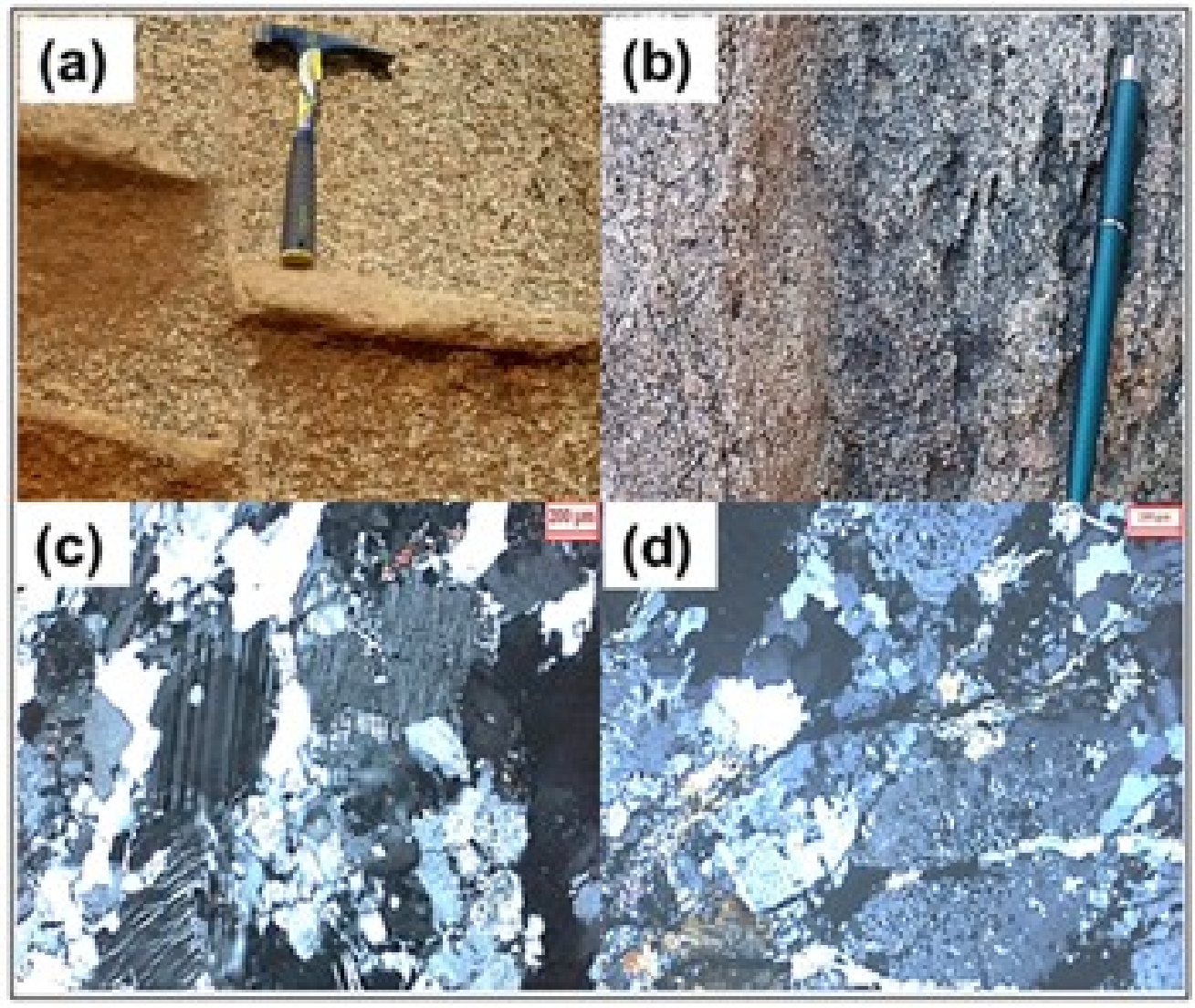

Figure 5.Field and microphotographs of Older Granite (grey). a- highly weatheredgrey coloured older granite showing displacement of felsic veins, b- grey granite in gradational contact with pink granite, $c$ photomicrograph showing deformation in perthite and feldspathisation (XPL) and d- grey granite showing alteration of biotite to chlorite. 


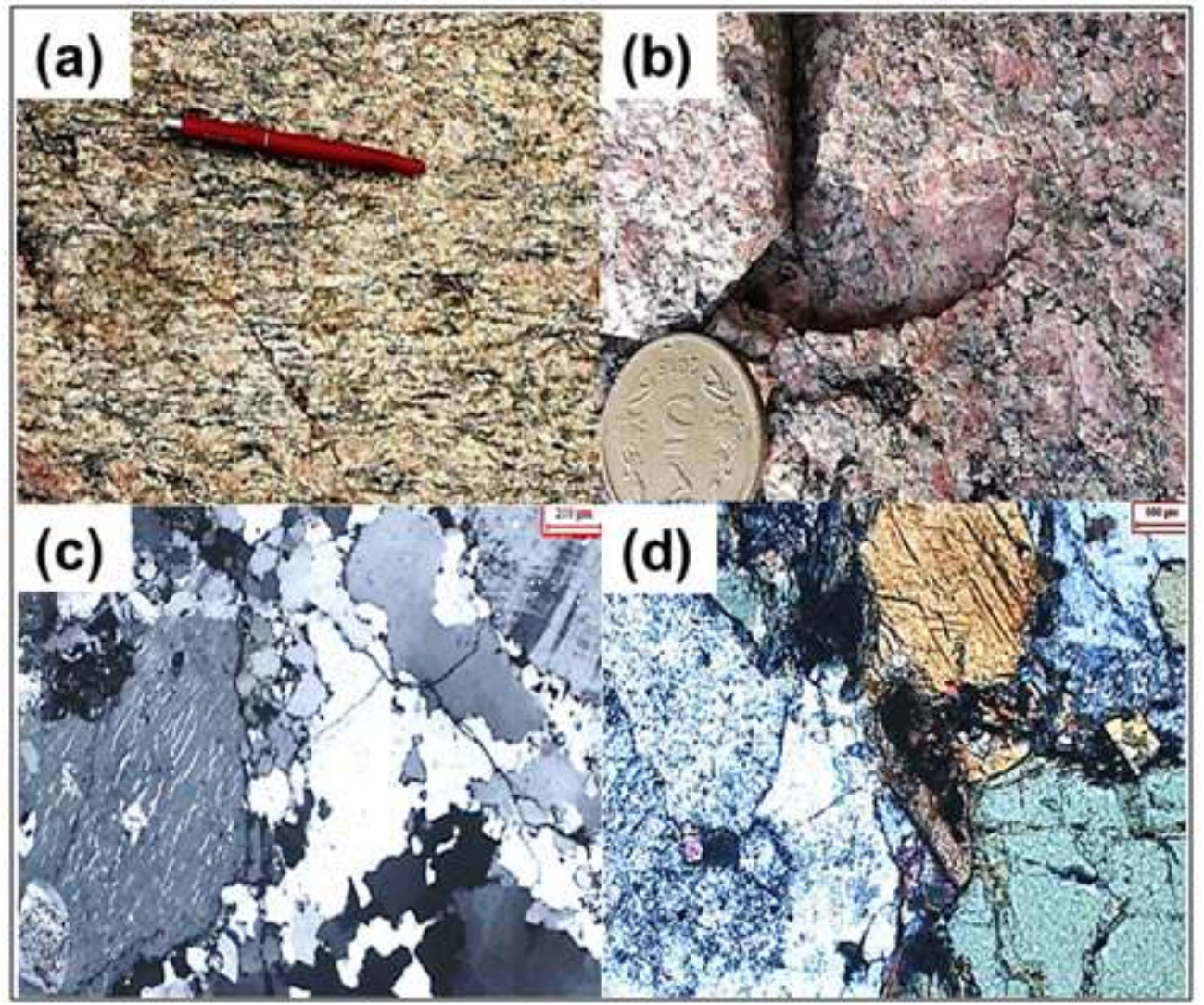

Figure 6. Field and microphotographs of Older Granite (pink). a- moderately weathered pink coloured older granite showing foliation, b- coarse grained porphyritic pink granite, $c$ - photomicrograph showing myrmekitic intergrowths (XPL) and d- pink granite showing alteration of biotite to chlorite.

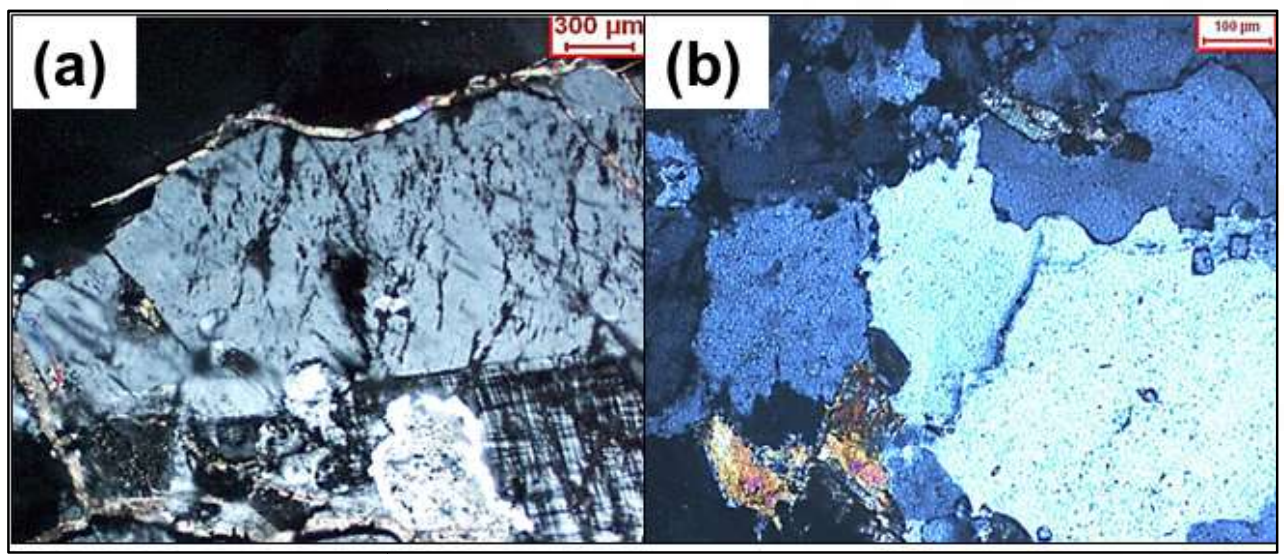

Figure 7. Photomicrographs showing older pink granite. a- albite under alteration to feldspar and bpink granite showing primary sphene and development of secondary sphene.

C. Younger Granites: The younger granitoids occur as intrusive bodies within the older granitoids. These rocks are grey to light grey in colour, medium to coarse grained and inequigranular textured with mafic enclaves (Fig.8a to c). At a hand scale, these rocks appear to be massive, hard and compact and micaceous quartzo-feldspathic in nature. Feebly developed foliations are observed. These rocks invariably possess medium grained mafic enclaves of augen/lensoid shape of different sizes.

Under the microscope, the younger granites display inequigranular, coarse grained texture. The essential mineral ingredients are plagioclase, amphibole, minor amount of alkali feldspar, quartz, chlorite, sphene, 
biotite and opaque minerals. Albite predominates over alkali feldspar and quartz and therefore they are presumed to be granodioritic in character. Like in the case of gneissic and older granitoids, in younger granites also, the feldspar is observed to be sericitised and contain chlorite rich veins cutting across. Biotite shows partially altered grain boundaries. Secondary biotite is associated with sphene and other opaque minerals (Fig.8d).

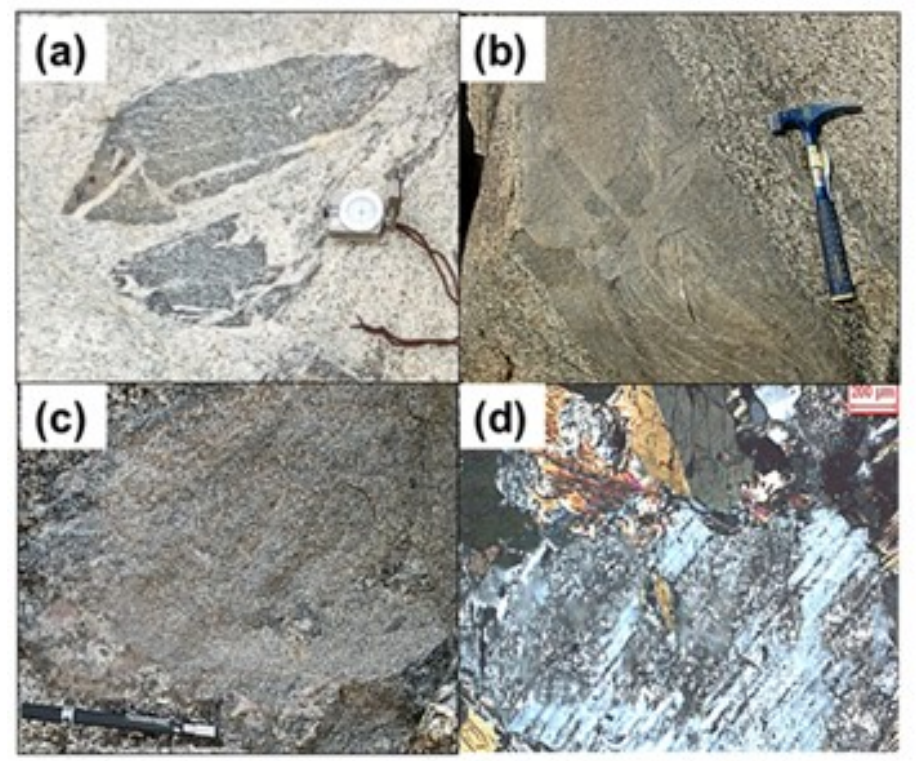

Figure 8: Field and microphotographs of younger granites. A- augen shaped mafic enclaves in younger grey granite. Note mixing of felsic component and minor deformation, b- medium grained mafic enclave in younger granite showing magma mixing, c- fine to medium grained mafic enclave within younger granite and dphotomicrograph showing biotite, amphibole under alteration to secondary biotite and sericitised feldspar.

\section{MODAL MINERALOGY}

Mineral modal analysis has been attempted to obtain quantitative variation in volume $\%$ of minerals and their relation in different rock types, using petrological research microscope. Modal values of perthite were included as alkali feldspar and free albite was assumed to be plagioclase as used by Maniar and Piccoli [9]. The results of the modal mineral analysis are shown in Table 2.

\begin{tabular}{|l|l|l|l|l|}
\hline Mineral & $\begin{array}{l}\text { Granite } \\
\text { Gneiss }\end{array}$ & $\begin{array}{l}\text { Older } \\
\text { Granite }\end{array}$ & $\begin{array}{l}\text { Younger } \\
\text { Granite }\end{array}$ & $\begin{array}{l}\text { Mafic } \\
\text { Enclave }\end{array}$ \\
\hline Quartz & 50 & 55 & 56 & 25 \\
\hline K-feldspar & 35 & 15 & 22 & 5 \\
\hline Plagioclase & 8 & 20 & 17 & 5 \\
\hline Biotite & 3 & 4 & 2 & 25 \\
\hline Hornblende & 2 & 3 & 1 & 30 \\
\hline Opaques & 2 & 3 & 2 & 10 \\
\hline
\end{tabular}

Table 2.Modal mineral abundances in granitoids and associated mafic enclaves.

\section{CONCLUSIONS}

The study area comprises mainly three petrographically distinguishable rock types viz., older, gneissic/foliated and younger granitoids. Even though mineralogically all the three types exhibit similarities, they exhibit differences in their petrographic characteristics. The granitoids of the study area exhibit different types of planar and foliated structures. Alteration of feldspar is observed in many places in thin-sections. The mafic enclaves are observed to be rich in mineral phases like biotite, hornblende and opaques with low amounts of felsic minerals. Presence of perthitic texture and primary biotite in the granitoids of the study area act as evidence of magmatic source for older granitoids. The presence of mafic and felsic enclaves of variegated sizes and shapes suggests the coexistence and mixing of both mafic and felsic magmas at the time of crystallisation.In and around Khatgaon, pyrite mineralisation is observed within felsic veins intruded into older granitoids.

\section{ACKNOWLEDGEMENTS}

S.S.M.Raj Kumar, Geologist, Cyient Limited is thanked for assistance in field. The Department of Geology, UCSS, Osmania University is thanked for allowing the authors to use the Petrology Lab. 


\section{REFERENCES}

1) S. M. Naqui and J. J. W. Rogers,"Precambrian geology of India", Oxford Monogr. Geol. Geophy.vol. 6, Clarendon Press, Oxford Univ. Press, pp..223, 1987.

2) P. R. Wasanekar, "Geological, Geochronological and Fluid Inclusion Thermocryometric studies of granite rocks around Degloor, Nanded district, Maharashtra", Ph.D. Thesis, Shivaji University, 241p., 1994. http://shodhganga.inflibnet.ac.in/handle/10603/14 2191

3) Hallowes K., "On some Infra trappian and Silicified lava from Hyderabad, South India", Geological Survey of India, Rec.Vol.49, Pt.

4) M. Jayananda J.F. Moyen , H. Martin, J.J. Peucat, B. Auvray and B. Mahabaleswar, "Late Archaean (2550-2520 Ma) juvenile magmatism in the Eastern Dharwar craton, southern India: Constraints from geochronology, $\mathrm{Nd}-\mathrm{Sr}$ isotopes and whole rock geochemistry", Precamb. Res., vol.99, pp.225-254, 2000.

5) GSI, "Metallogenic map of India", Scale 1: 2.5 million, Geological Survey of India, Second Edition, 2003.

6) Y. J. Bhaskar Rao, T.V. Sivaraman, , G.V.C. Pantula, K. Gopalan and S. M. Naqui, "Rb-Sr ages of Late Archaean metavolcanics and granites, Dharwar Craton, South India and evidence for Early Proterozoic thermotectonic events", Precambrian Research, vol.59, pp. 145-170, 1992.

7) R. H. Vernon, "Crystallization and hybridism in microgranitoid enclave magmas: Microstructural evidence", J. Geophys. Res., vol.95(17),pp. 849$859,1990$.

8) B. Barbarin and J. Didier, "Genesis and evolution of mafic microgranular enclaves through various types of interaction between coexisting felsic and mafic magmas", Earth Environ. Sci. Trans. Roy. Soc. Edinb., vol.83, pp. 145-153, 1992. doi: 10.1017/S0263593300007835.

9) P. D. Maniar and P.M. Piccoli, "Tectonic discrimination of granitoids". Bull. Geol. Soc. Am. vol.101, pp. 635-643, 1989. 